\title{
SPIRITUALITAS DAN KESUKSESAN BELAJAR: Studi Meta Analisis
}

\author{
M. Nur Ghufron \\ STAIN Kudus, Jawa Tengah, Indonesia \\ emnurghufron78@gmail.com
}

\begin{abstract}
Abstrak
Penelitian ini adalah meta-analisis mengenai hubungan antara spirituailitas dan keberhasilan belajar. Meta-analisis bertujuan untuk menyimpulkan, mengintegrasikan dan menginterpretasikan data dari penelitian terdahulu. Oleh karena itu, karena sangat tergantung pada penelitian utama, data yang akan dianalisis melalui metode ini harus memiliki konstruk yang sama dan pola korelasi sehingga dapat dibandingkan satu dengan lainya. Penelitian ini lakukan secara kuantitatif dengan mereview 14 penelitian dari 15 artikel dengan sampel gabungan berjumlah 3119. Analisis yang dilakukan berupa mengoreksi kesalahan sampling dan kesalahan pengukuran. Hasil analisis menunjukkan bahwa spirituailitas memiliki korelasi dengan keberhasilan belajar. Hasil penelitian menunjukkan bahwa spirituailitas dapat menjadi sebagai prediktor keberhasilan belajar .

Kata kunci: spirituailitas, keberhasilan belajar dan meta analisis
\end{abstract}

\begin{abstract}
SPIRITUALITY AND LEARNING SUCCESS: META ANALYSIS STUDY. This Study used meta-analysis of the relationship between spirituality and learning success. Meta-analysis aimed at concluding, integrating, and interpreting data gathered from previous research.
\end{abstract}


Therefore, this sreseach was apart from acting as primary research. The data was analyzed through this method must have the same constructs and correlation patterns so that it could be compared with one another. The quantitative review included 14 studies from 15 articles that contained a combined sample of approximately 3119. This analysis extended previous work by directly correcting error of sampling and measurements. Summary analysis provided support that had a correlation on learning success spirituality. The result showed that spirituality has been identified as predictors and learning success.

Keywords: spirituality, learning success and meta- analysis

\section{A. Pendahuluan}

Spiritualitas dan agama memiliki hubungan dengan aspek kognitif, emosional, perilaku, interpersonal dan psikologis yang membentuk sebagai pendekatan holistik untuk memahami individu. Banyak penelitian telah membahas agama dan spiritualitas yang mempengaruhi dalam kehidupan manusia.

Banyak penelitian telah dilakukan mengenai peran spiritualitas terhadap aspek-aspek kehidupan manusia dan hasilnya telah bervariasi. Misalnya hasil penelitian Pargament \& Park (1997: 43-53) yang menunjukkan bahwa individu yang lebih religius atau spiritual, dan menggunakan spiritualitasnya untuk mengatasi hidup, mengalami banyak manfaat untuk kesehatan dan kesejahteraan. Penelitian Koenig dan Larson (2001: 67-78) serta hasil penelitian Gartner et al (1991: 6-25) yang telah menemukan bahwa religiusitas berkorelasi positif dengan penyesuaian, beberapa penelitian juga telah menemukan bahwa religiusitas berkorelasi negatif dengan penyesuaian, misalnya hasil penelitian Schaefer (1997: 633). Sementara hasil penelitian Lewis, et al (1997:119) justru tidak menemukan hubungan yang signifikan sama sekali.

Secara tradisional spiritualitas berkaitan erat atau identik dengan konsep religiusitas. Namun, selama bertahun-tahun, meskipun telah banyak usaha yang telah dilakukan, masih sedikit kesepakatan yang dicapai mengenai kedua istilah tersebut (Zinnbauer et al, 1997: 549). Menurut Hill et al. (2000: 66) spiritualitas didefinisikan sebagai "perasaan, pikiran, pengalaman, dan perilaku yang muncul dari pencarian yang suci”. Istilah 
'suci' mengacu pada dewa, objek ilahi, hakekat kebenaran yang dirasakan oleh individu". Spiritualitas dalam konteks ini dapat terjadi di dalam atau di luar konteks agama. Dengan demikian definisi agama lebih kompleks. Hill et al. (2000: 66) memberikan pengertian agama sama dengan spiritualitas yaitu "perasaan, pikiran, pengalaman, dan perilaku yang muncul dari pencarian yang suci" Istilah 'suci' mengacu pada dewa, objek ilahi, hakekat kebenaran yang dirasakan oleh individu. Namun, dalam konteks pencarian untuk suci itu juga dapat mencakup tujuan non-sakral (misalnya, identitas, rasa memiliki, makna, dan kesehatan).

Menurut Boadella (dalam Reyes, 2006: 12), religiusitas berasal dari kata Latin yaitu religere, yang berarti berhubungan kembali dengan sumber yang lebih dalam. Sementara Gazalba (dalam Ghufron, 2012: 57) berpendapat bahwa Religiusitas berasal dari kata religi bahasa latin"religio" yang akar katanya adalah religure yang berarti mengikat. Pengertian ini mengandung makna bahwa religi atau agama pada umumnya memiliki aturan-aturan dan kewajiban-kewajiban yang harus dipatuhi dan dilaksanakan oleh pemeluknya. Semua itu berfungsi untuk mengikat seseorang atau sekelompok orang dalam hubungan dengan Tuhan, sesama manusia dan alam sekitarnya.

Berbagai definisi dari dua konsep telah diusulkan oleh para ahli yang berbeda dengan berbagai pandangan mulai dari polarisasi dari dua konsep tersebut, keterkaitan antara spiritualitas dan agama, sampai ada pula beberapa ulama yang menyarankan salah satunya menjadi subdomain dari yang lain, sementara ulama lain menyarankan berlawanan. Reich (1996:149) menyebutkan empat cara yang bisa dilakukan untuk menggambarkan hubungan antara religiusitas dan spiritualitas, yaitu: bahwa keduanya adalah domain yang terpisah, bahwa keduanya adalah domain yang berbeda tetapi tumpang tindih, bahwa keduanya adalah sama, dan bahwa salah satu adalah subdomain bagi yang lain. Kelly (1995: 227) mengemukakan bahwa spiritualitas merupakan pengalaman subjektif seseorang dari transendental sifat alam semesta sementara agama dianggap ekspresi institusional dalam menampilkan spiritualitas. Spiritualitas adalah pengalaman universal, kurang dibatasi oleh doktrin terkait dengan agama tertentu. 
Benson, et al (2003: 208) mendukung kemungkinan bahwa ada tumpang tindih yang signifikan antara agama dan spiritualitas, tetapi kedua perkembangan agama dan pengembangan spiritual memiliki dimensi yang berada di luar domain yang lain. Demikian pula, Wagener \& Maloney (2006: 139) menunjukkan bahwa spiritualitas memiliki potensi untuk menjawab pertanyaanpertanyaan utama yang intrinsik berkaitan pengalaman menjadi manusia. Wilayah kerohanian termasuk pengalaman transendensi, baik yang baik dan yang jahat, memiliki hubungan dengan makna dan tujuan. Hal ini merupakan fungsi integratif yang mengarah ke pengalaman keutuhan pribadi dan hubungan antara diri sendiri dan ciptaan, menemukan individu dalam sistem transendensi makna. Agama, di sisi lain, adalah keyakinan bersama dan struktur sosial di mana spiritualitas terutama terbentuk dari agama menurut sebagian besar manusia. Dengan demikian, spiritualitas mencakup pencarian makna, untuk kesatuan, untuk keterhubungan, transendensi, dan yang merupakan potensi tertinggi yang dimiliki manusia.

Pargament membedakan antara religiusitas dan spiritualitas. Pargament menggambarkan religiusitas sebagai sesuatu yang tradisional dan melembaga, sementara spiritualitas dianggap non-tradisional dan individualistis. Pargament melihat konstruk religiusitas sebagai sesuatu yang berubah, misalnya, "kehilangan kekayaannya, keluasan dan potensi". Pargament melihat pergeseran persepsi dengan spiritualitas yang dilihat dari sisi yang positif, sedangkan religiusitas dipandang lebih negative (Pargament, 1999: 15). Pargament mendefinisikan agama dalam arti luas dan multidimensi termasuk ekspresi keagamaan institusional, seperti dogma dan ritual, dan ekspresi keagamaan, seperti perasaan spiritualitas, keyakinan tentang yang suci, dan agama adalah praktek.

Berbeda dengan Pargament, Hodge et al (2010: 3) menganggap spiritualitas menjadi lebih luas konsepnya, yang mewakili keyakinan transenden dan nilai-nilai yang mungkin atau mungkin tidak terkait dengan organisasi keagamaan. Religiusitas di sisi lain mengacu pada ritual dan kepercayaan, yang mungkin ditunjukkan dalam konteks lembaga keagamaan. Spiritualitas 
dapat dinyatakan dalam konteks agama tetapi religiusitas seseorang tidak selalu karena spiritualitas.

Mengingat definisi spiritualitas dan agama yang disebutkan di atas bervariasi, maka kiranya bijaksana untuk mempertimbangkan pendapat Singleton et al (2004: 250) dalam menawarkan definisi spiritualitas dengan kesadaran tujuan hidup berdasarkan rujukan transenden. Bahwa definisi spiritual tidak leksikal. Ini berarti bahwa Singleton tidak membuat klaim bahwa definisi spiritualitasnya adalah ringkasan dari bagaimana orang lain menggunakan konsep tersebut. Singleton et al (2004:250) juga tidak bertujuan untuk membangun definisi secara definitif konsep tersebut. Sebaliknya, Singleton menawarkan definisi stipulatif berupa konsep kompleks dalam hal apa artinya spiritualitas dalam suatu konteks atau pembahasan tertentu.

Berdasarkan penjelasan di atas dapat ditegaskan bahwa spiritualitas lebih luas daripada agama namun saling terkait dengan agama (Benson et al., 2003: 208). Pada tulisan ini, kata spiritualitas dan agama akan digunakan secara bersamaan dan terkadang secara bergantian.

Sementara istilah kesuksesan belajar dalam penelitian ini sama dengan prestasi belajar serta kadang-kadang digunakan secara berganti-ganti dengan istilah prestasi akademik. Istilah kesuksesan belajar mengandung makna yaitu hasil yang diperoleh dari aktivitas-aktivitas belajar berupa penguasaan pengetahuan atau keterampilan, lazimnya ditunjukkan dengan nilai tes atau angka nilai.

Para peneliti sering menggunakan Indeks Prestasi Komulatif (IPK) atau nilai rapor untuk menentukan tingkat prestasi akademik mata pelajaran yang telah dicapai. Pengukuran IPK merupakan indikator nyata dari prestasi akademik yang sudah tersedia, berguna dalam analisis kuantitatif, dan telah cukup bagus dalam memprediksi kesuksesan di masa depan pendidikan dan karir siswa. Namun demikian, IPK bukan satu-satunya cara untuk mengukur prestasi, juga tidak selalu mengukur pembelajaran secara akurat. Penilaian kelas yang dilaporkan sendiri juga sering digunakan karena mudah untuk mendapatkan melalui survei. 


\section{Hubungan Antara Spiritualitas dengan Kesuksesan}

Belajar. Penelitian tentang hubungan spiritualitas dengan kesuksesan belajar bukan hal yang baru. Beberapa Peneliti sering menggunakan spiritualitas atau agama sebagai prediktor untuk perilaku pembelajaran maupun perilaku lainnya. Sebagai contoh, sebuah studi terbaru yang dipublikasikan dalam Journal of Youth and Adolescence disurvei pada anak laki-laki dan perempuan di kelas 9-12 untuk menentukan apakah ada hubungan antara spiritualitas atau agama dengan masalah penyalahgunaan zat adiktif dan prestasi akademik. Para peneliti menemukan bahwa agama dapat memprediksi tingkat yang lebih rendah penggunaan zat sebaliknya, sementara itu untuk agama tidak berkorelasi positif dengan prestasi akademik (Good \& Willoughby, 2011: 680).

Peneliti lain akhir-akhir ini berkonsentrasi pada spiritualitas, dan prestasi akademik dan telah menemukan bahwa spiritualitas berhubungan dengan keberhasilan akademis (Riggins et al, 2008: 70-81). George et al (2008: 714) menemukan bahwa Spiritualitas adalah prediktor signifikan dari nilai IPK. Penelitian tersebut menemukan bahwa waktu yang dihabiskan dalam ibadah spiritual secara signifikan berkorelasi dengan IPK. George, et al. (2008: 714) juga melaporkan bahwa meskipun ukuran spiritualitas berdampak sedikit pada IPK, namun spiritualitas adalah prediktor terkuat penentu kesuksesan individu. Mooney (2010: 198) melaporkan bahwa siswa yang terlibat dalam kegiatan keagamaan atau spiritual mempunyai (1) kepuasan yang lebih besar dengan kehidupan sosial di kampus, (2) lebih evaluasi positif saat berinteraksi dengan siswa lain, (3) lebih tinggi secara keseluruhan peringkat kepuasan pengalaman kuliahnya, dan (4) yang lebih tinggi rata-rata Indeks Prestasi (IPK).

Penelitian ilmiah berkembang secara eksplosif di mana para peneliti di berbagai bidang kajian memproduksi serta mengunggulkan hasil dari studi empirisnya mengenai hubungan antara variabel yang menjadi ketertarikannya. Banyaknya informasi hasil penelitian seringkali membuat tidak mungkin bagi para peneliti dan sarjana untuk memiliki gambaran tentang pengembangan dan kesatuan yang berkontribusi terhadap gambaran keseluruhan dari penelitian lapangan. Selanjutnya, 
temuan sering bertentangan dan menyebabkan kebingungan di kalangan peneliti ketika berusaha untuk menarik kesimpulan umum dari penelitian sebelumnya. Sebuah metode untuk sintesis kuantitatif temuan penelitian adalah meta-analisis, yang menerapkan teknik statistik untuk meringkas bagian data empiris dalam domain penelitian. Pendekatan meta-analisis telah berkembang dalam popularitas selama dekade terakhir dan dianggap sebagai gelombang masa depan dalam menangani sintesis temuan penelitian (Kock, 2009: 2).

Ghufron (2013: 465-480) telah melakukan penelitian secara meta analisis terhadap hubungan antara religiusitas dengan kesuksesan akademik yang hasilnya menunjukkan bahwa religiusitas dapat dijadikan prediktor terhadap kesuksesan akademik. Sementara penelitian secara spesifik yang menghubungkan spiritualitas dengan kesuksesan belajar masih langka atau bahkan belum ada secara meta analisis. Oleh karena itu perlu ditegaskan bahwa, tujuan dalam penelitian ini adalah untuk menguji beberapa penelitian diluar Indonesia mengenai pengaruh spiritualitas terhadap kesuksesan belajar.

Pengumpulan data diperoleh dari, Ebsco, Proquest, Dissertation Abstract dan Dissertation Abstract International antara tahun 2008 sampai tahun 2016. Kata kunci yang digunakan adalah "spirituality", "Academic success", "Academic performance" "Academic achievement". Oleh karena penelitian ini untuk melakukan analisis dengan menggunakan pendekatan metaanalisis secara kuantitatif, maka data yang digunakan adalah: (a) jumlah Subjek (N), (b) salah satu dari nilai korelasi r, F, atau t, (c) bila item b tidak disertakan, maka naskah harus mencantumkan rerata skor (M) dan standar deviasi (SD). Berdasarkan langkah tersebut diperoleh sejumlah 15 naskah.

Analisis data penelitian dilakukan melalui empat tahap: pertama, Manajemen data. Beberapa penelitian yang telah dilakukan mengenai hubungan religiusitas dengan kesuksesan akademik tidak hanya menguji satu dimensi religiusitas saja atau satu kesuksesan akademik saja. Ada beberapa dimensi yang diukur, dan terkadang ada pula dimensinya yang berbeda antara penelitian yang satu dengan lainnya walaupun nama variabelnya sama, bahkan 
ada pula sebaliknya variabelnya berbeda tapi maknanya bisa dikategorikan sama sehingga perlu dilakukan pengkodean. Kedua, pengkodean dilakukan dengan mengkelompokkan variabel yang kurang lebih maknanya mendekati religiusitas dan kesuksesan akademik. Ketiga, untuk data yang masih mengandung nilai F, $\mathrm{t}$, atau d dikonversikan terlebih dahulu ke nilai $\mathrm{r}$ sehingga siap diperbandingkan. Keempat, dengan mengikuti pendapat Hunter \& Schmidt (2004: 80) bahwa kesalahan sampling ini memberikan dampak tidak terstruktur dan sangat dipengaruhi besarnya sampel dan koreksi kesalahan pengukuran, sehingga dalam penelitian ini selanjutnya menggunakan dua koreksi terhadap data yang diperoleh berupa koreksi kesalahan pengambilan sampel dengan alasan kesalahan pengambilan sampel (sampling error) adalah artefak yang paling banyak mencemari hasil dari penelitian.

Menurut Sugiyanto (2008: 1-8), langkah-langkah dalam melakukan koreksi kesalahan pengambilan sampel bisa dilakukan dengan mencari estimasi $r$ populasi, varian $r$ populasi terbobot, varian $r$ populasi kesalahan pengambilan sampel dan estimasi varian $r$ populasi. Langkah yang ditempuh dalam melakukan koreksi kesalahan pengukuran dengan menentukan kesalahan pengukuran pada salah satu variabel atau dua variabel sekaligus, mencari reliabilitas intstrumen, koreksi kesalahan pengukuran $\mathrm{x}$ dan $y$, rerata kesalahan pengukuran pada $\mathrm{x}$ dan $\mathrm{y}$ sampai akhirnya estimasi $r$ populasi.

\section{B. Pembahasan}

Hasil seleksi terhadap data terdiri dari 15 variabel bebas dan 15 variabel tergantung dengan 14 studi. Data-data yang memenuhi syarat untuk dianalisis dapat dilihat pada tabel 1 .

\section{Tabel 1.}

Tabulasi data penelitian yang memenuhi syarat untuk dianalisis

\begin{tabular}{cccccccc}
\hline No & Penelitian & V. Bebas & V. Tergantung & N & rxy & A & b \\
\hline 1 & Oslon, L., G. & Religious & Grade Point & 74 & 0.29 & 0 & 0 \\
& $(2008)$ & $\begin{array}{c}\text { Spiritual } \\
\text { Well-Being }\end{array}$ & Average & & & & \\
& & & & & & \\
\hline
\end{tabular}




\begin{tabular}{|c|c|c|c|c|c|c|c|}
\hline No & Penelitian & V. Bebas & V. Tergantung & $\mathbf{N}$ & rxy & $\mathbf{A}$ & $\mathbf{b}$ \\
\hline 2 & $\begin{array}{c}\text { Schubmehl, } \\
\text { Cubbellotti } \\
\text { dan Van } \\
\text { Omum } \\
(2009)\end{array}$ & $\begin{array}{c}\text { Effect of } \\
\text { spirituaility }\end{array}$ & $\begin{array}{c}\text { Grade Point } \\
\text { Averages } \\
\text { (GPA) }\end{array}$ & 247 & 0.49 & 0 & 0 \\
\hline 3 & $\begin{array}{l}\text { Rachel } \\
\text { George .M } \\
\text { \& Visvam, } \\
\text { S. (2013) }\end{array}$ & $\begin{array}{c}\text { Spiritual } \\
\text { Intelligence }\end{array}$ & $\begin{array}{c}\text { Academic } \\
\text { achievement }\end{array}$ & 125 & 0.279 & 0 & 0 \\
\hline 4 & $\begin{array}{l}\text { Beauvais, A., } \\
\text { M. Stewart, } \\
\text { J., G. \& } \\
\text { DeNisco, S. } \\
(2014)\end{array}$ & $\begin{array}{c}\text { Spiritual } \\
\text { well-being }\end{array}$ & $\begin{array}{l}\text { Academic } \\
\text { Success }\end{array}$ & 124 & 0.198 & 0.99 & 0 \\
\hline 5 & $\begin{array}{l}\text { Singh, T. } \\
(2014)\end{array}$ & $\begin{array}{c}\text { Spiritual } \\
\text { Intelligence }\end{array}$ & $\begin{array}{c}\text { Academic } \\
\text { achievement }\end{array}$ & 883 & 0.12 & 0.81 & 0 \\
\hline 6 & $\begin{array}{l}\text { Aghaei, H., } \\
\text { Behjat, F. \& } \\
\text { Rostampour, } \\
\text { M. (2014) }\end{array}$ & $\begin{array}{c}\text { Spiritual } \\
\text { Intelligence }\end{array}$ & $\begin{array}{l}\text { Language } \\
\text { Proficiency }\end{array}$ & 60 & 0.869 & 0 & 0 \\
\hline 7 & $\begin{array}{c}\text { Davaoudi, R. } \\
\text { \& Nezhad, } \\
\text { Z., A., Z. } \\
(2014)\end{array}$ & $\begin{array}{c}\text { Spiritual } \\
\text { Intelligence }\end{array}$ & Creativity & 360 & 0.308 & 0.85 & 0.89 \\
\hline 8 & $\begin{array}{l}\text { Bolghan- } \\
\text { Abadi, M., } \\
\text { Ghofrani, } \\
\text { F. \& Abde- } \\
\text { Khodaei, M., } \\
\text { S. (2014) }\end{array}$ & Life spiritual & $\begin{array}{c}\text { Students' } \\
\text { Quality of Life }\end{array}$ & 143 & 0.34 & 0 & 0.84 \\
\hline 9 & $\begin{array}{l}\text { Bolghan- } \\
\text { Abadi, M., } \\
\text { Ghofrani, } \\
\text { F. \& Abde- } \\
\text { Khodaei, M., } \\
\text { S. (2014) }\end{array}$ & $\begin{array}{c}\text { Spiritual } \\
\text { Intelligence }\end{array}$ & $\begin{array}{c}\text { Students' } \\
\text { Quality of Life }\end{array}$ & 143 & 0.42 & 0.89 & 0.84 \\
\hline
\end{tabular}




\begin{tabular}{|c|c|c|c|c|c|c|c|}
\hline No & Penelitian & V. Bebas & V. Tergantung & $\mathbf{N}$ & rxy & $\mathbf{A}$ & $\mathbf{b}$ \\
\hline 10 & $\begin{array}{l}\text { Chuku, P., } \\
\text { O. (2014) }\end{array}$ & Spirituality & $\begin{array}{c}\text { Grade Point } \\
\text { Averages } \\
\text { (GPA) }\end{array}$ & 101 & 0.21 & 0.97 & 0 \\
\hline
\end{tabular}

\begin{tabular}{|c|c|c|c|c|c|c|}
\hline 11 & $\begin{array}{l}\text { Ali Khan, } \\
\text { S.,Kausar, } \\
\text { Y.\&Vijayshri } \\
\text { (2014) }\end{array}$ & $\begin{array}{c}\text { Spiritual } \\
\text { well-being }\end{array}$ & $\begin{array}{c}\text { Achievement } \\
\text { Motivation }\end{array}$ & 100 & -0.406 & $0.93 \quad 0.83$ \\
\hline
\end{tabular}

\begin{tabular}{|c|c|c|c|c|c|c|c|}
\hline 12 & $\begin{array}{c}\text { Motakallem, } \\
\text { A. }(2014)\end{array}$ & $\begin{array}{c}\text { Spiritual } \\
\text { Intelligence }\end{array}$ & $\begin{array}{c}\text { Work } \\
\text { Performance } \\
\text { of School } \\
\text { Principals } \\
\end{array}$ & 250 & 0.239 & 0.92 & 0.74 \\
\hline 13 & $\begin{array}{l}\text { Pour, F., K. } \\
\text { \& Golshan, } \\
\text { M. (2015) }\end{array}$ & $\begin{array}{c}\text { Spiritual } \\
\text { Intelligence }\end{array}$ & $\begin{array}{c}\text { students' } \\
\text { success in a } \\
\text { general English } \\
\text { course }\end{array}$ & 109 & -0.023 & 0 & 0 \\
\hline 14 & $\begin{array}{l}\text { Bashir, H. } \\
\text { \& Bashir L. } \\
(2016)\end{array}$ & $\begin{array}{c}\text { Self } \\
\text { Regulation }\end{array}$ & $\begin{array}{c}\text { Spiritual } \\
\text { Intelligence }\end{array}$ & 300 & 0.437 & 0 & 0 \\
\hline 15 & $\begin{array}{c}\text { Villagonzalo, } \\
\text { R., R. } \\
(2016)\end{array}$ & $\begin{array}{l}\text { Spiritual } \\
\text { Quotient }\end{array}$ & $\begin{array}{l}\text { Academic } \\
\text { Performace }\end{array}$ & 100 & 0.147 & 0 & 0 \\
\hline
\end{tabular}

Berikut ini, hasil koreksi kesalahan pengambilan sampel dan kesalahan pengukuran yang menguji hubungan antara spiritualitas dan kesuksesan belajar.

\section{Koreksi kesalahan pengambilan sampel untuk menguji hubungan antara spiritualitas dengan kesuksesan belajar}

Analisis perhitungan koreksi terhadap kesalahan pengambilan sampel didapatkan 15 studi, dengan melibatkan total subjek 3119 orang. Angka korelasi yang dilaporkan arahnya positif. Hasil koreksi terhadap kesalahan pengambilan sample diperoleh estimasi $r$ populasi (rerata $r$ ) $=0.245$ dengan varian korelasi populasi terbobot $\mathrm{Sr}^{2}=0.03922$, varian korelasi kesalahan pengambilan sampel $\mathrm{Se}^{2}=0.00513$ dan estimasi varian korelasi populasi $\sigma \rho r^{2}=0.03409$. Adapun dampak kesalahan pengambilan 
sampel sebesar $15.04 \%$. Hasil perhitungan koreksi artefak kesalahan pengambilan sampel hubungan antara spiritualitas dengan kesuksesan belajar dapat dilihat pada tabel 2 .

Tabel. 2.

Rangkuman data perhitungan koreksi artefak kesalahan pengambilan sampel hubungan spiritualitas dengan kesuksesan belajar.

\begin{tabular}{lc}
\hline Keterangan & Hasil \\
\hline Jumlah Sampel $(\mathrm{N})$ & 3119 \\
\hline Total $\mathrm{r}$ & 3.917 \\
\hline estimasi r populasi atau rerata $\mathrm{r}(\dot{\mathrm{r}})$ & 0.245 \\
\hline varian korelasi populasi terbobot $\left(\mathrm{Sr}^{2}\right)$ & 0.03922 \\
\hline varian korelasi kesalahan pengambilan sampel $\left(\mathrm{Se}^{2}\right)$ & 0.00513 \\
\hline estimasi varian korelasi populasi $\left(\mathrm{srr}^{2}\right)$ & 0.03409 \\
\hline dampak kesalahan pengambilan sampel sebesar & $15.04 \%$ \\
\hline
\end{tabular}

Adapun dengan dampak kesalahan pengambilan sampel sebesar $15 \%$, persentase yang kecil ini menunjukkan kemungkinan bias kesalahan karena kekeliruan dalam pengambilan sampel adalah kecil.

\section{Koreksi kesalahan pengukuran untuk menguji hubungan antara Spiritualitas dengan kesuksesan belajar}

Hasil rincian koreksi terhadap artefak pengukuran, diperoleh rerata kesalahan pengukuran A sebesar 0.134789046, sedangkan estimasi korelasi populasi $(\rho)$ sebesar 1.815835453, jumlah koefisien kuadrat variasi (V) sebesar 3.372665831, varian yang mengacu variasi artefak $\left(\mathrm{s}^{2} 2\right)$ sebesar 0.202039133 , varians korelasi populasi sesungguhnya $\operatorname{Var}(\mathrm{r})$ sebesar -9.244304169, dan interval kepercayaan (rr) sebesar 0,1190896. Adapun dampak variasi reliabilitas $333.0 \%$. Hasil perhitungan koreksi artefak kesalahan pengukuran untuk menguji hubungan antara spiritualitas dengan kesuksesan belajar, dapat di lihat pada tabel 


\section{Tabel. 3}

Rangkuman data perhitungan koreksi artefak kesalahan pengukuran untuk menguji hubungan antara spiritualitas dengan kesuksesan belajar.

\begin{tabular}{lc}
\hline Keterangan & Hasil \\
\hline Jumlah Sampel $(\mathrm{N})$ & 3119 \\
\hline Jumlah Studi & 15 \\
\hline rerata kesalahan pengukuran $(\mathrm{A})$ & 0.134789046 \\
\hline estimasi korelasi populasi $(\mathrm{r})$ & 1.815835453 \\
\hline Jumlah koefisien Kuadrat variasi $(\mathrm{V})$ & 3.372665831 \\
\hline Varian yang mengacu variasi artefak $\left(\mathrm{s}^{2} 2\right)$ & 0.202039133 \\
\hline Varians korelasi populasi sesungguhnya Var (r) & -9.244304169 \\
\hline interval kepercayaan (rr) & 0.1190896 \\
\hline Dampak variasi reliabilitas & $333.0 \%$ \\
\hline
\end{tabular}

Melihat hasil interval kepercayaan (rr) sebesar 333.0\%, dan hasilnya lebih besar daripada dampak kesalahan pengambilan sampel, maka dapat menunjukkan pula bahwa kemungkinan bias kesalahan karena kekeliruan dalam pengukuran adalah lebih besar.

Hasil meta analisis dampak kesalahan pengambilan sampel hubungan antara spiritualitas dengan kesuksesan belajar sebesar $15 \%$, maka dapat disimpulkan prosentase faktor lain yang belum teridentifikasi sebesar $85 \%$. Selanjutnya, temuan dari meta analisis ini mengungkapkan kemungkinan bias dampak variasi reliabilitas adalah lebih besar. Dengan melakukan spesifikasi riset dalam menguji pengaruh spiritualitas pada kesuksesan belajar, didapatkan bahwa hipotesis yang mengatakan bahwa ada hubungan antara spiritualitas dengan kesuksesan belajar dapat diterima.

Sebagaimana yang telah dijelaskan di awal tulisan ini, kesuksesan belajar dalam penelitian ini merupakan keberhasilan individu setelah menjalani serangkaian kegiatan belajar, dengan demikian prestasi belajar dapat pula dikatakan sebagai tolok ukur 
berhasil atau tidaknya proses belajar. Kesuksesan belajar dapat yang dinyatakan dalam bentuk aspek kualitatif seperti mempunyai kepribadian, motivasi belajar, kepercayaan diri, penyesuaian diri, integritas yang baik. Sementara dalam bentuk aspek kuantitaif seperti mendapat hasil nilai pelajaran, rapor, ujian nasional atau indeks prestasi kumulatif yang tinggi.

Mendapatkan kesuksesan belajar yang baik merupakan suatu dambaan setiap siswa, mahasiswa, orangtua dan pendidik setelah menjalani proses pembelajaran. Namun, menentukan apa saja yang menyebabkan siswa atau mahasiswa bisa mencapainya bukanlah tugas yang mudah untuk dilakukan.

Beberapa ahli psikologi dan pendidikan mencoba mengemukakan berbagai faktor yang dapat mempengaruhi kesuksesan akademik. Winkel (1996:226) mengemukakan beberapa faktor yang mempengaruhi proses dan prestasi belajar, antara lain: 1) karakteristik individu, mencakup karakteristik psikis dan fisik; 2) pengajaran, mencakup materi pelajaran dan keterampilan mengajar; 3) bahan atau materi yang akan dipelajari, mencakup jenis materi, tingkat kesukaran dan kompleksitas; 4) media pengajaran, mencakup jenis media yang dipakai dan penggunaannya; 5) karakteristik sekolah, gedung dan fasilitas belajar; dan 6) lingkungan dan situasi, meliputi lingkungan alam seperti suhu, musim dan iklim. Secara umum, faktor-faktor yang mempengaruhi prestasi akademik dapat dibedakan menjadi dua macam, yakni; a) faktor internal, yakni keadaan/kondisi jasmani dan rohani individu, dan b) faktor eksternal, yakni kondisi lingkungan di sekitar individu.

Kesuksesan belajar individu juga ditentukan oleh kecerdasan yang dimiliki. Dwick dan Leggett (dalam Tasaki, 2001: 13) berpendapat bahwa ada dua teori yang terkandung dari kecerdasan: (a) teori kecerdasan incremental dan (b) teori kecerdasan kesatuan (entity). Mereka yang percaya teori incremental cenderung memandang kecerdasan dapat dirubah, dan dapat diperbaiki. Berbeda, mereka yang memufakati teori kecerdasan kesatuan percaya bahwa kecerdasan tidak dapat berubah dan menetap. Dua kepercayaan tentang kecerdasan mengarahkan untuk bereaksi dengan cara yang berbeda-beda ketika menjalankan 
aktivitas belajar termasuk pendekatan belajarnya. Individu yang memegang kepercayaan incremental cenderung untuk melihat aktivitas belajar sebagai suatu kesempatan untuk meningkatkan kecerdasan. Pada sisi lain, individu dengan kepercayaan kesatuan merasa aktivitas belajar tidak banyak berpengaruh terhadap aktivitas belajarnya dan hanya sebagai suatu kesempatan untuk menguji kecerdasan mereka saja.

Spiritualitas atau agama sebagai kebutuhan paling mendasar bagi setiap manusia, mempunyai fungsi dan pengaruh yang kuat bagi diri individu untuk mengatasi dan menyikapi berbagai permasalan yang sukar, menekan dan mengganggu ketahanan mental individu. Spiritualitas memiliki dampak positif, tidak hanya membebaskan manusia dari rasa kegelisahan dan kecemasan, bahkan hubungan rohaniah antara manusia dan Tuhannya, memberi harapan, menguatkan kemauan, dan membekali kekuatan yang luar biasa sehingga memungkinkan manusia untuk dapat menghadapi segala permasalahan dan melaksanakan tugas dengan baik. Melalui keyakinan akan kemampuan berpengaruh besar terhadap kemampuan itu. Seseorang yang berusaha mendapatkan sesuatu sesuai dengan harapan dan keyakinannya akan meningkatkan kematangan diri sehingga dapat semakin berhasil dan mendapatkan harapannya seperti nilai pelajaran, indeks prestasi yang tinggi.

Hasil secara keseluruhan studi meta analisis ini memperkuat landasan teori yang dipakai dalam studi meta analisis ini. Bahwa spiritualitas mempunyai pengaruh terhadap kesuksesan belajar. Individu yang mempunyai spiritualitas yang tinggi akan mempunyai kesuksesan dalam belajar yang tinggi pula. Oleh karena individu-individu dengan spiritualitas yang tinggi lebih efektif dan gigih dalam menghadapi kesulitankesulitan dan kegagalan terutama yang berkaitan dengan menghadapi pemecahan masalah kehidupan khususnya dalam dunia pendidikan, mereka lebih mungkin untuk mencapai hasil yang bernilai dan memperoleh hasil belajar yang lebih baik. 


\section{Simpulan}

Banyak teori dalam psikologi pendidikan yang mencoba menjelaskan, mengarahkan dan memprediksi berbagai hal yang berkaitan dengan potensi diri pada manusia termasuk kesuksesan belajar. Penelitian tentang spiritualitas yang dikaitkan dengan kesuksesan belajar telah banyak dilakukan. Demikian ini di karenakan spiritual adalah perasaan, pikiran, pengalaman, dan perilaku yang muncul dari pencarian yang suci yang menjadi pemicu individu-individu dengan spiritualitas yang tinggi lebih efektif dan gigih dalam menghadapi kesulitan-kesulitan dan kegagalan dan lebih mungkin untuk mencapai hasil belajar yang lebih sukses.

Hasil penelitian ini menunjukkan bahwa dampak kesalahan pengambilan sampel sebesar $15 \%$, persentase yang kecil ini menunjukkan kemungkinan bias kesalahan karena kekeliruan dalam pengambilan sampel adalah kecil. Sementara hasil interval kepercayaan (rr) sebesar 333.0\%, dan hasilnya lebih besar daripada dampak kesalahan pengambilan sampel, maka dapat menunjukkan pula bahwa kemungkinan bias kesalahan karena kekeliruan dalam pengukuran adalah lebih besar.

Berdasarkan hasil penelitian ini telah membuktikan bahwa ada pengaruh spiritualitas terhadap kesuksesan belajar. Hasil penelitian meta-analisis ini sebagaimana hasil penelitian meta analisis lainnya mempunyai beberapa keterbatasan. Pertama, penemuan meta-analisis adalah korelasi secara alami dan, oleh karena itu, tidak bisa menjamin kesimpulan-kesimpulan yang kuat. Kedua, keseluruhan penemuan dari meta-analisis sering dibatasi oleh mutu studi-studi utama. Ketiga, pengaruh budaya, termasuk berbagai latar belakang etnis terabaikan. Khusus ketika melakukan penelitian di Indonesia karena kebanyakan bahkan semua hasil penelitian yang digunakan dalam studi ini berasal dari luar negeri (luar Indonesia), dan mungkin masih banyak pertimbangan bila disesuaikan dengan kondisi di Indonesia.

Penelitian masa depan diharapkan dapat meliputi kriteriakriteria yang lebih ketat untuk memastikan bahwa beberapa faktor lain bisa dimasukkan seperti dengan melihat spesifikasi alat ukur spiritualitas yang digunakan, gender, budaya atau 
diperluas kriterianya guna menguji pengaruhnya terhadap alat ukur kesuksesan akademik yang spesifik pula. Demikian ini, hasil penelitian ini dapat menjadi petunjuk yang lebih spesifik bagi penelitian selanjutnya. Bahwa spiritualitas mempunyai pengaruh terhadap kesuksesan akademik. Untuk penelitian lainnya diharapkan mampu bersikap lebih kritis dalam memandang suatu hasil penelitian. Suatu hasil penelitian tidak dapat dipercaya secara penuh mengingat adanya artefak atau kesalahan yang dilakukan peneliti. 


\section{DAFTAR PUSTAKA}

Aghaei, H., Behjat, F. \& Rostampour, M. 2014. Investigating the relationship between Iranian high school female students' spiritual intelligence, language proficiency and self-esteem. International Journal of Language and Linguistics, 2, 19-27.*

Ali Khan, S.,Kausar, Y.\&Vijayshri 2014. Spiritual well-being in relation to achievement motivation students of science and commerce streams. Indian Journal of Health and Wellbeing, 5(1), 53-56.*

Bashir, H. \& Bashir L. 2016. Infestigating the relationship between self-regulation and spiritual intelligence of higher secondary school students. Indian Journal of Health and Wellbeing, 7(3), 327-329.*

Beauvais, A., M. Stewart, J., G. \& DeNisco, S. 2014. "Factors Related to Academic Success Among Nursing Students: A Descriptive Correlational Research Study. Nurse Education Today 34.(6) : 918-23. *

Benson, P. L., Roehlkepartain, E. C., \& Rude, S. P. 2003. Spiritual development in childhood and adolescence: Toward a field of inquiry. Applied Developmental Science, 7, 204-212.

Bolghan-Abadi, M., Ghofrani, F. \& Abde-Khodaei, M., S. 2014. Study of the Spiritual Intelligence Role in Predicting University Students' Quality of Life. J Relig Health53:7985. *

Chuku, P., O. 2014. Assessing The Relationship Between Gender Difference, Spirituality And Academic Performance Among African American College Students. Dissertation. North Carolina Central University: Durham. *

Davaoudi, R. \& Nezhad, Z., A., Z. 2014. Relationship between spiritual intelligence and creativity of secondary school students. Indian Journal of Health and Wellbeing, 5 (11), 1316-1320. * 
Gartner, J., D., B., Larson, dan Allen, G. D. 1991. Religious commitment and mental health: A review of the empirical literature. Journal of Psychology and Theology 19, 6-25.

George, D., Dixon, S., Stansal, E., Gelb, S.L., \& Pheri, T. 2008. Time diary and questionnaire assessment of factors associated with academic and personal success among university undergraduates. Journal of American College Health, 56(6), 706-715.

Ghufron, M. N. 2013. Apakah Religiusitas Berpengaruh Terhadap Kesuksesan Akademik? Studi Meta Analisis. Dalam Proceding in The Annual International Conference on Islamic Studies (AICIS) ke-13 IAIN Mataram 18-21 November 2013, Mataram: Direktorat Pendidikan Tinggi Islam Republik Indonesia.

Ghufron, M. N., 2012. Psikologi Epistemologis: Kepercayaan tentang Hakekat Pengetahuan dan bagaimana Mengetahui Perspektif Psikologi, Yogyakarta: Penerbit Idea Press

Good, M. \& Willoughby T. 2011. Evaluating the direction of effects in the relationship between religious versus nonreligious activities. Journal of Youth and Adolescence, 40, 680-693.

Hill, P. C., Pargament, K. I., Hood, R. W., Jr., McCullough, M. E., Swyers, J. P., Larson, D. B., \& Zinnbauer, B. J. 2000. Conceptualizing religion and spirituality: Points of commonality, points of departure. Journal for the Theory of Social Behaviour, 30, 51-77.

Hodge, D. R., Bonifas, R. P.\& Jing-Ann Chou, R. 2010. Advances in Social Work, 11( 1), 1-16

Hunter, J. E., Schmidt, F. L., 2004, Methods of Meta-Analysis : Correcting Error and Bias in Research Findings. London; Sage Publications

Hunter, J.E., \& Schmidt, F.L. 1990. Methods of Meta Analysis, Correcting Error and Bias Research Findings. London; Sage Publications 
Kelly, E. W. Jr. 1995. Spirituality and religion in counselor education: A national survey. Counselor Education and Supervision, 33, 227-237.

Kock, Alexander 2002. A Guide to Meta Analysis. TIM Working Paper, vol. 2. Berlin: Technische Universität Berlin

Koenig, H. G. dan Larson, D., B. 2001. Religion and mental health: Evidence for an association. International Review of Psychiatry 13, 67-78

Lewis, C, A,, C, Lanigan, S, Joseph, dan J, de Fockert. 1997. Religiosity and happiness: No evidence for an association among undergraduates. Personality and Individual Differences 22, 119-21,

Mooney, M. 2010. Religion, College Grades, and Satisfaction Among Students at Elite Colleges and Universities. Sociology of Religion, 71(2), 197-215.

Motakallem, A. 2014. Role of Personality Traits and Spiritual Intelligence in Predicting Work Performance of School Principals. International Journal of Basic Sciences \& Applied Research., 3, 14-18. *

Oslon, L., G. 2008. An Investigation Of Factors That Influence Academic Achievement In Christian Higher Education: Emotional Intelligence, Self-Esteem And Spiritual WellBeing. Dissertation. Minnessota: Capella University. *

Pargament, K.I., 1999, The Psychology of religion and spirituality? Yes and No. The International Journal for the Psychology of Religion, 9, 3-16

Pargament, K. I., \& Park, C. L. 1997. In times of stress: The religion-coping connection. In B. Spilka, \& D. N. McIntosh (Eds.), The psychology of religion: Theoretical approaches (pp. 43-53). Boulder, CO: Westview Press.

Polanski, P. J. 2002, January. Exploring spiritual beliefs in relation to Adlerian Theory. Counseling and Values, 46, 127-136.

Pour, F., K. \& Golshan, M. 2015. The Role of Spiritual Intelligence in EGP Progress Test. International Journal of Educational Investigations, 2 (11), 71-78. * 
Rachel George .M \& Visvam, S. 2013. Spiritual Intelligence, its correlation with Teacher Effectiveness and Academic achievement-A Study. International Journal of Education and Psychological Research 2, (2), 106-110.*

Reich, K. 1996. A logic-based typology of science and theology. Journal of Interdisciplinary Studies 8: 149-67.

Reyes, G. M. 2006. Spirituality and Religiosity: Their Relation to Academic Achievement of Undergraduate College Students. Dissertation. Arizona: Northern Arizona University

Riggins, R. K., McNeal, C., \& Herndon, M. K. 2008. The Role of Spirituality among African-American College Males Attending a Historically Black University. College Student Journal, 42(1), 70-81.

Schaefer, W. E. 1997. Religiosity, spirituality, and personal distress among college students. Journal of College Student Development 38, 633-44.

Schubmehl, J., Cubbellotti, C dan Van Omum, W. 2009. The Effect Of Spirituality And Campus Ministry On Academic Accomplishment In College Students. Adolescence, 44, (174) 499-502

Schubmehl, J., Cubbellotti, S., dan Van Omum, W. 2009. The Effect of Spirituality and Campus Ministry on Academic Accomplishment in College Students. Adolescence, 44 (174), 499-502.*

Singh, T. 2014. Role of Spiritual Intelligence, Altruism and Mental Health in predicting Academic Achievement. International Journal of Education, Issue December . 3, 1-8. *

Singleton, A., Mason, M., \& Webber, R. 2004. Spirituality in adolescence and young adulthood: A method for a qualitative study. International Journal of Children's Spirituality, 9(3), 247-262.

Sugiyanto, 2008. Metaanalisis korelasi, Bahan perkuliahan Metode Kuantitatif Program Doktor Psikologi (Tidak Diterbitkan). Yogyakarta: Fakultas Psikologi Universitas Gadjah Mada, hal 1-8 
Tasaki, K. 2001. Culture And Epistemology: An Investigation of Different Patterns in Epistemological Beliefs Across Culture. Unpublished doctoral dissertation. University of Hawaii.

Villagonzalo, R., R. 2016. Intelligence Quotient, Emotional Quotient, Spiritual Quotient, And Adversity Quotient ${ }^{\circ}$ And The Academic Performance Of Students. Dissertation. St. Alexius College: City of Koronadal *

Wagener, LM \& Moloney, HN 2006. 'Spiritual and religious pathology in childhood and adolescence', in The Handbook of spiritual development in childhood and adolescence', eds EC Roehlkepartain, PE King, L Wagener \& PL Benson, pp.137-149, California: Sage Publications

Winkel, W.S. 1996. Psikologi Pengajaran. Jakarta: PT. Grasindo.

Zinnbauer, B.J., Pargament, K.I., Cole, B., Rye, M.S., Butter, E. M., Belavich, T. G., Hipp, K.M., Scott, A. B., Kadar, J.L., Journal for the Scientific Study of Religion, 36(4), 549-564

Referensi yang bertanda bintang $\left({ }^{*}\right)$ dibelakang adalah jurnal yang digunakan dalam meta analisis. 
